\title{
THE IMPACT OF NATURE CONSERVATION TYPES ON THE HOUSE INVESTMENTS DEVELOPMENT
}

\author{
Pawel Mickiewicz ${ }^{1}$, Professor; Maciej J. Nowak ${ }^{2}$, PhD., \\ ${ }^{1,2}$ Faculty of Economics, West Pomeranian University of Technology Szczecin, Poland
}

\begin{abstract}
The objective of the article is to determine a relationship between the development of housing investments and the degree of terrain coverage with nature protection forms. The data concerning the number of building permits issued in districts and the coverage of those districts with nature forms were compared. The gathered data were verified through the application of a correlation analysis. In this way one of the correlation planes between the implementation of investments and nature protection was determined. The research results indicate relation between the location of nature conservation type and house investments.
\end{abstract}

Key words: local development, nature protection forms, housing investments.

JEL code: R11, R58.

\section{Introduction}

According to the concept of sustainable development, environmental and natural values must coexist with other objects to a certain degree. The requirement of reconciling different conditions also refers to reconciling natural values and investment development, including housing investments. In this context, the application of nature protection instruments, including designation of nature protection forms, may constitute one of the collision points of different qualities.

The purpose of the article is to define the relationship between the development of housing investments and the degree of terrain coverage with nature protection forms. It will involve both a statistical analysis of the data covering the West Pomeranian Province, as well as an extensive reflection concerning the contact points of both these spheres. The subject of research concerns new house investments development in districts, depending on the degree of their coverage by the form of nature protection. In order to achieve the research objective, the data concerning the number of building permits issued in individual years for housing investments along with the data concerning the degree of coverage of districts with nature protection forms were gathered. Following that, on the basis of a correlation analysis, an attempt was undertaken at defining the scope of correlations existing between such data - both in all the districts of the West Pomeranian Province, as well as in the districts featuring specific properties from the point of view of the research assumptions.

\section{Research results and discussion Development of housing investments}

The need for the development of housing investments is emphasised and implemented in the policy of many countries (Cowem T., 1998). Recent solutions implemented in Poland can serve as an example of that. Those solutions raise numerous doubts of procedural nature as well as doubts related to their compliance with the system of land management. Nevertheless, the above does not change the fact that the development of housing investments, from the perspective of the national economy, social needs related thereto, is fully desirable. Presently it is demonstrated in Poland in particular through the following solutions proposed:

- the creation of National Public Real Estate Resources. The implementation of investments related to those resources and renting the real estate from those resources would be aimed, on the one hand, at offering facilitations for an investor, and on the other hand, at creating rent offers for a community;

\footnotetext{
${ }^{1}$ Corresponding author. Tel.: +48914496900; E-mail address: pmickiewicz@zut.edu.pl

2 Corresponding author. Tel.: +48914496900; E-mail address: macnowak@zut.edu.pl
} 
- the so-called special purpose housing act, enabling the implementation of larger housing investments irrespectively of a spatial order existing in a given municipality (in land planning acts).

The doubts related to those solutions and the problems involving their implementation do not change the fact that housing needs really do need to be fulfilled (Krueger A., 1991). From the perspective of land management, this issue brings about some spatial conflicts (Nowak M., Mickiewicz P., 2012) and a question of to what degree can "the need for the implementation of housing investments" serve as a justification for the destruction of other space assets. However, the sigs of "struggle for space" are still noticeable in that sphere. Thus, various concepts and plans are confronted. In the analysed context one more aspect becomes evident: on the basis of the contents of the studies regarding conditions and directions of spatial development as well as local zoning plans it is possible to determine a definite overestimation of the sites designated for housing development in those documents. It is a paradox of sorts: on the one hand, in the land planning dimension this sphere is chaotically overestimated, and on the other hand, particularly in regulatory sphere, insufficient resources of housing policy are still felt (which also entails the implementation of new housing investments). This is one of the examples of a land management system crisis in Poland, as well as an example of the lack of a consistent and categorical differentiation of land planning and regulatory spheres, as well as maintaining the cohesion between them. This dissonance needs to be kept in mind when analysing the issue undertaken in the article.

It is also possible to differentiate these conflicts in the objective and subjective aspects. From the perspective of this article, a conflict between (widely understood) housing investors and the authorities in charge of nature conservation seems to be crucial. In other words, on the one hand the conflict entails extensive investment development (justified by the necessity to satisfy the society's housing needs) and the protection of natural values (Furuboth E., Pejovich S., 1974).

\section{Nature conditions and nature protection forms}

The objective issue needs to be examined also from a different perspective. The study ought to answer a question whether natural values, particularly the ones extensively present in a given area (Schumpeter J., 2005), constitute a barrier to the development of housing investments. Additionally, the issue may be analysed multi-dimensionally, but one of the most important elements of such an analysis involves a comparison of the processes related to investment implementation in various local-government units, covered to a different degree by nature protection forms. It is the scope in which these forms are present in given areas that will constitute one of the crucial points of reference. In the literature of the subject the objective related to universal nature conservation raises No doubts. It involves:

- maintaining ecological processes, ecosystems stability and maintaining or reinstating natural habitats to their proper condition;

- maintaining biological diversity;

- conservation of landscape amenities;

- shaping proper attitudes towards nature among people (Poskrobko B., 2007).

The concrete fulfilment of those objectives is based primarily institutionally (Williamson O., 2000) on nature protection forms. It is the establishment, location of such forms in a given area that constitutes an expression of the fulfilment of all the tasks stipulated above. Territorial forms of nature protection include: national parks, nature reserves, landscape parks, protected landscape areas, 
Natura 2000 areas. In this context it needs to be noted where the limitations in land-use planning originate from with regard to nature protection forms. These forms constitute ways of counteracting the degradation of nature values (limited though they may be). The impact of the economy on natural environment has been frequently judged to be excessively high, the evidence of which is the designation of environmental risk areas in Poland. According to E. Mazur, the greatest impact on the natural environment is exerted by:

- industrial activity;

- urbanization activity (along with municipal services);

- transportation activity (Mazur E., 2010).

An analysis of concrete effects must be adjusted to particular terrain functions. Nature protection forms cover most of them. D. Laguna provided an interesting description of individual stages of the degradation of nature values in suburban areas, in which a particular urban pressure is evident (Laguna D., 2009). In this perspective, the process entails the following:

- zoning of building plots, which comprise terrains unsuited for development from geotechnical point of view (owners decide on such a division because they wish to gain the highest profits possible);

- making building development gradually denser by reducing land plot surface or increasing building development density (owners, particularly property developers, aim to zone the smallest possible plots and to reach the highest possible unit price);

- eliminating publicly accessible green areas from all land-use planning solutions: they are maintained only in those localities where there is No formal and legal possibility of converting them for the purpose of building development.

In the context of the analysed issue, the following conclusion may be drawn:

- as a rule, the implementation of a new building development leads to the destruction of nature values of the terrain involved;

- the sole effective protection in those circumstances (referring not to the entire sphere of environment protection, but to nature protection) entails the establishment of nature protection forms. Other types of limitations (though introduced in the sphere of zoning policy) may be incidental at the most, with an exceptionally restricted range of impact.

In this situation one may view the relationships between housing investments and nature protection forms in a variety of ways. The location of a nature protection form may be perceived as a barrier, even if just from the perspective of a cursory, simple analysis. Its consequences include limitations and prohibitions of building development on specific terrains. However, the scope of limitations introduced on account of specific protection forms and the scale of investments in the protection zones of some of those investments will remain a contentious issue. What is more, the assumption presented above would need to be combined with a concept according to which an investor entitled to carry out building development should have an opportunity of implementing an investment in possibly the largest terrain and in this sense the development in itself remains a significant quality (Mc Cann B., Folta T., 2008). However, the considerations related to spatial order force us to question this point of view.

\section{Housing investments and nature protection forms}

The study includes the districts located in the West Pomeranian Province. In this province an extensive range of territorial nature protection forms has been implemented. From the standpoint of 
this article the districts that are significant are the ones qualified in the Local Data Bank of the Main Statistical Office for the implementation of nature protection forms and which may be assessed from the perspective of the number of building permits issued (the authority issuing permits is a district head, being a part of a district authorities structure).

Table 1

Percentage share of the terrain designated for nature protection form in the total district area (\%)

\begin{tabular}{|l|c|c|c|c|c|c|c|}
\hline No. & Year & $\mathbf{2 0 1 1}$ & $\mathbf{2 0 1 7}$ & No. & Year & $\mathbf{2 0 1 1}$ & $\mathbf{2 0 1 7}$ \\
\hline 1. & Bialogardzki & 0.27 & 0.3 & 10. & Mysliborski & 44.06 & 43.6 \\
\hline 2. & Choszczenski & 54.43 & 54.6 & 11. & Policki & 3.29 & 3.3 \\
\hline 3. & Drawski & 43.33 & 47 & 12. & Pyrzycki & 0.05 & 0.1 \\
\hline 4. & Goleniowski & 3.5 & 8.8 & 13. & Slawienski & 13.72 & 15 \\
\hline 5. & Gryficki & 0.59 & 0.7 & 14. & Stargardzki & 10.75 & 10.6 \\
\hline 6. & Gryfinski & 24.51 & 24.5 & 15. & Szczecinecki & 28.53 & 28.9 \\
\hline 7. & Kamienski & 7.61 & 7.4 & 16. & Swidwinski & 14.08 & 15.2 \\
\hline 8. & Kolobrzeski & 6.89 & 6.4 & 17. & Walecki & 51.49 & 51.7 \\
\hline 9. & Koszalinski & 20.36 & 20.5 & & & &
\end{tabular}

Source: author's calculation based on the Local Data Bank of the Main Statistical Office

In the Table 1, a percentage share of nature protection forms in the entire district area was presented for 2011 and for 2017 (i.e. the start and end of the research period). The differences in these cases are only slight. At this juncture, Choszczno, Drawsko, Mysliborz and Walcz districts need to be emphasised as the ones that are covered by nature protection forms to the highest degree (districts significantly covered by nature protection forms). The districts that need to be distinguished as being specific include: Gryfino, Goleniow and Police district (districts located in a metropolitan area). In those districts nature protection forms are present to a scant degree. At the same time, parts of those districts are subject to suburbanisation process on account of their close proximity to the province capital - Szczecin.

The subsequent part of the analyses concerns the relationship between the location of nature protection forms and the realized housing investments. For the purpose of the research it was assumed that in the analysed context the most adequate reflection of the latter involves the information on the building permits issued in individual years in a district. Such an assumption was made for the following reasons:

- building permits constitute the most universal form of a building consent, equivalent to being granted the possibility of investment implementation;

- their issue at the same time contains an assessment of a building design compliance with all and any other limitations and guidelines, including the ones related to the limitation on building development due to the location of nature protection forms;

- their issue constitutes an expression of public authorities' operation.

At a later stage obviously, construction works are subject to verification (or in some cases also occupancy permits are issued). However, from this perspective the widest substantive assessment takes place earlier. That is why it was assumed that the moment of issuing a decision regarding a building permit is equivalent to a formal approval of the presented conditions relative to a building design. It is chiefly at that point when limitations linked to nature protection forms may block an investment. 
Number of building permits for one-family buildings

\begin{tabular}{|l|c|c|c|c|c|c|c|}
\hline \multicolumn{1}{|c|}{ Year } & $\mathbf{2 0 1 1}$ & $\mathbf{2 0 1 2}$ & $\mathbf{2 0 1 3}$ & $\mathbf{2 0 1 4}$ & $\mathbf{2 0 1 5}$ & $\mathbf{2 0 1 6}$ & $\mathbf{2 0 1 7}$ \\
\hline Bialogardzki & 52 & 55 & 45 & 48 & 61 & 67 & 92 \\
\hline Choszczenski & 73 & 81 & 69 & 58 & 76 & 64 & 85 \\
\hline Drawski & 93 & 91 & 100 & 75 & 83 & 80 & 92 \\
\hline Goleniowski & 272 & 201 & 165 & 191 & 200 & 200 & 249 \\
\hline Gryficki & 116 & 128 & 113 & 121 & 142 & 135 & 174 \\
\hline Gryfinski & 169 & 152 & 126 & 106 & 138 & 160 & 156 \\
\hline Kamienski & 131 & 149 & 136 & 125 & 145 & 152 & 176 \\
\hline Kolobrzeski & 170 & 116 & 105 & 106 & 117 & 152 & 199 \\
\hline Koszalinski & 393 & 327 & 254 & 307 & 288 & 305 & 402 \\
\hline Mysliborski & 101 & 83 & 91 & 68 & 95 & 102 & 153 \\
\hline Policki & 376 & 216 & 212 & 169 & 207 & 288 & 352 \\
\hline Pyrzycki & 69 & 64 & 49 & 34 & 55 & 68 & 65 \\
\hline Slawienski & 139 & 102 & 74 & 108 & 96 & 79 & 99 \\
\hline Stargardzki & 226 & 200 & 219 & 206 & 262 & 313 & 344 \\
\hline Szczecinecki & 83 & 82 & 83 & 75 & 105 & 113 & 155 \\
\hline Swidwinski & 57 & 53 & 47 & 48 & 50 & 56 & 55 \\
\hline Walecki & 77 & 76 & 63 & 61 & 95 & 75 & 84 \\
\hline
\end{tabular}

Source: author's calculation based on the Local Data Bank of the Main Statistical Office

First of all, the building permits issued for one-family buildings were subjected to analysis (Tab.2). In the districts featuring the most extensive degree of coverage by nature protection forms a lower number of building permits issued is indeed observed in comparison to other districts. In turn, in the districts at least partially belonging to Szczecin Metropolitan Area, the number of permits is decidedly higher. This observation obviously does not at this stage allow one to draw any farther conclusions. On the one hand, there is No doubt that a proximity to a large city translates into a greater range of investments (which can be concluded without the analysis of Tab.2). On the other hand, a lower number of permits in given districts may also result from other factors than natural ones, be it a distance from larger centres. Nevertheless, already at the present stage of the analysis the observed trends are worth indicating. Simultaneously, one more thing needs to be noted: as a rule, in the examined period the number of building permits issued within a year is increasing. It is most certainly not a result of previously mentioned statutory changes, since they do not refer to one-family houses. 
Number of building permits for multi-family buildings

\begin{tabular}{|l|c|c|c|c|c|c|c|}
\hline \multicolumn{1}{|c|}{ Year } & $\mathbf{2 0 1 1}$ & $\mathbf{2 0 1 2}$ & $\mathbf{2 0 1 3}$ & $\mathbf{2 0 1 4}$ & $\mathbf{2 0 1 5}$ & $\mathbf{2 0 1 6}$ & $\mathbf{2 0 1 7}$ \\
\hline Bialogardzki & 3 & 0 & 4 & 0 & 2 & 3 & 3 \\
\hline Choszczenski & 4 & 1 & 0 & 0 & 1 & 2 & 0 \\
\hline Drawski & 1 & 2 & 1 & 5 & 6 & 2 & 0 \\
\hline Goleniowski & 7 & 4 & 6 & 7 & 3 & 5 & 10 \\
\hline Gryficki & 2 & 1 & 2 & 3 & 3 & 6 & 8 \\
\hline Gryfinski & 4 & 5 & 2 & 0 & 4 & 1 & 6 \\
\hline Kamienski & 9 & 7 & 5 & 6 & 12 & 9 & 8 \\
\hline Kolobrzeski & 7 & 10 & 10 & 12 & 12 & 7 & 20 \\
\hline Koszalinski & 12 & 18 & 5 & 12 & 4 & 16 & 13 \\
\hline Mysliborski & 4 & 2 & 1 & 1 & 4 & 2 & 2 \\
\hline Policki & 36 & 15 & 26 & 39 & 39 & 50 & 69 \\
\hline Pyrzycki & 2 & 1 & 0 & 1 & 1 & 1 & 1 \\
\hline Slawienski & 5 & 2 & 1 & 3 & 0 & 0 & 0 \\
\hline Stargardzki & 3 & 6 & 2 & 6 & 8 & 11 & 12 \\
\hline Szczecinecki & 3 & 0 & 0 & 3 & 6 & 3 & 9 \\
\hline Swidwinski & 0 & 1 & 0 & 1 & 0 & 1 & 1 \\
\hline Walecki & 2 & 0 & 1 & 3 & 0 & 5 & 4 \\
\hline
\end{tabular}

Source: author's calculation based on the Local Data Bank of the Main Statistical Office

The next stage of studies involved isolating the number of building permits issued in individual districts for multi-family buildings. From Table 3 it arises that in this aspect the number of issued decisions is influenced by a variety of factors, the best example of which is a number of building permits issued in Kolobrzeg district (which is linked to the investments implemented in urban terrains that are attractive for touristic reasons). However, once again, the number of decisions issued in the districts located in a metropolitan area that prevails over a small number of decisions issued in the districts covered significantly by nature protection forms will be noticeable.

It also ought to be noted that the number of objective decisions in the examined districts is not growing (which confirms a proposition of limited efficiency of governmental programmes). Nevertheless, the presented Figures may constitute the basis for determining the existence of a risk posed to spatial order by uncontrollable building development.

Analysis of the correlation between the numbers of building permits issued and the area of a district covered by nature protection forms

\begin{tabular}{|l|c|c|c|c|c|c|c|}
\hline \multicolumn{1}{|c|}{ Year } & $\mathbf{2 0 1 1}$ & $\mathbf{2 0 1 2}$ & $\mathbf{2 0 1 3}$ & $\mathbf{2 0 1 4}$ & $\mathbf{2 0 1 5}$ & $\mathbf{2 0 1 6}$ & $\mathbf{2 0 1 7}$ \\
\hline One-family & -0.3 & -0.25 & -0.24 & -0.28 & -0.26 & -0.33 & -0.3 \\
\hline Multi-family & -0.24 & -0.2 & -0.38 & -0.28 & -0.23 & -0.29 & -0.31 \\
\hline
\end{tabular}

Source: author's calculation based on the Local Data Bank of the Main Statistical Office

On the grounds of preliminary analyses, further studies were conducted (Tab. 4). A Pearson correlation coefficient was determined in the following data pairs:

- the number of building permits issued for one-family buildings and a percentage share of the district covered by nature protection forms;

- the number of building permits issued for multi-family buildings and a percentage share of the district covered by nature protection forms.

The choice of data is justified in terms of the fulfilment of the research objective. It was assumed that the location of nature protection forms may constitute one of the factors affecting the scope of housing investment implementation. That is why it is justified to compare both groups of data. 
Differentiating between the decisions issued for one-family and multi-family buildings is justified chiefly by differing economic effects of both those administrative decisions. One must additionally bear in mind that, as a rule, in both cases separate categories of investors will predominate, each having different capabilities of influencing public authorities.

From Table 4 it arises that in all the examined years in both pairs there is a negative correlation. This would preliminarily confirm the proposition that the number of building permits issued and the share of the areas covered by nature protection forms are correlated. However, one must take into account that in the scale of all the studied districts a significant correlation has not been achieved. That means that the presented results may be treated as preliminary ones at the most, ones that do not allow for the formulation of an unequivocal conclusion. As previously demonstrated, in certain examined districts the numbers of decisions regarding building permits are affected by entirely different factors.

Table 5

\begin{abstract}
Analysis of the correlation between the number of building permits issued and the area of a district covered by nature protection forms in the districts covered by nature protection forms to a significant degree and in the district located in close proximity to Szczecin
\end{abstract}

\begin{tabular}{|l|c|}
\hline \multicolumn{1}{|c|}{ Year } & $\mathbf{2 0 1 1}$ \\
\hline One-family & -0.87 \\
\hline Multi-family & -0.59 \\
\hline
\end{tabular}

Source: author's calculation based on the Local Data Bank of the Main Statistical Office

Bearing in mind the above, subsequent studies were conducted (Tab. 5). The districts covered by nature protection forms to a significant degree as well as the districts located in metropolitan areas were selected. Within the scope of a correlation analysis, the numbers of building permits for the years 2011 - 2017 were compared together with a percentage share of the area of the districts covered by nature protection forms. The analysis conducted for the specified districts in total (49 pairs were compared twice) leads to a negative significant correlation.

The choice of these districts is fully justified. It is in their territory that the collision of urban pressure with the objectives of nature conservation will occur most extensively (obviously, in both groups of districts for different reasons). The significance of correlation confirms unequivocally the proposition that both factors are correlated. It is important in this respect that in the districts covered by nature protection forms not only the terrains covered by nature protection forms are taken into consideration, but so are the terrains located in those districts that are not covered by such forms, or the ones subject to prohibitions. In those terrains there are No objective formal and legal contraindications for the implementation of housing investments (within a much larger scope than the one actually realized). From Table 5 it arises that the impact of nature protection forms also refers to those terrains.

\title{
Conclusions
}

The fact of the actual limitation in the number of building permits issued in the districts covered by nature protection forms to a significant degree should unequivocally be assessed positively, particularly in the context of the issues related to the increase of spatial chaos and the limitation of nature values. The positive aspect is that such advanced nature protection instruments as nature protection forms fulfil their intended goals in their basic scope. This does not change the fact that both in terms of the tasks related to widely-understood nature protection as well as in terms of comprehensive shaping of space, they are not sufficient solutions. The inability of public authorities, 
particularly at the central level (legislative level), needs to be noted in that regard. As demonstrated above, nature protection within the scope exceeding nature protection forms currently assumes various degrees, at times having highly limited effectiveness. The solution ought to involve comprehensive improvement, a change of land management system, within the scope of which social and economic planning would become integrated.

The confirmation of a correlation between the number of issued decisions regarding building permits and the percentage share of a district covered by nature protection forms leads to yet another conclusion. Effective nature protection is possible; however, it ought to constitute a more significant inspiration in the entire planning process.

\section{Bibliography}

1. Cowem, T. (1998). PUBLIC GoOdS AND EXTERNALITIES (w:) T. Cowen (red.) The Theory of Market Failure. A Critical Examination, George Mason University Press, Fairfax, p. 1.

2. Furuboth, E., Pejovich, S. (1974). THE ECONOMICS OF PROPERTY RIGHTS, Ballinger Publishing Company, Cambridge, pp. 367.

3. Krueger, A. (1991). GOVERNANCE FAILURES IN DEVELOPMENT, NBER, Working Paper No 3340/1991, Cambridge, p. 4.

4. Laguna, D. (2009). Rola obszarow przyrodniczych w ksztaltowaniu przestrzeni podmiejskiej (The role of natural areas in shaping the suburban space) (w:) T. Markowski, D. Drzazga (red.) System przyrodniczy w zarzadzaniu rozwojem obszarow metropolitalnych, Studia KPZK PAN, t. CXXIII, Warszawa, p. 82.

5. Mazur E. (2010). Srodowisko przyrodnicze jako podstawa bytu i dzialalnosci czlowieka (w:) K. Machowski (red.) Gospodarka a srodowisko i ekologia, CeDeWu, Warszawa, p. 27.

6. Mc Cann, B., Folta, T. (2008). LOCATION MATTERS. WHERE WE HAVE BEEN AND WHERE WE MIGHT GO IN AGGLOMERATION RESEARCH "Journal of Management" No 34/2008, p. 534.

7. Nowak, M., Mickiewicz, p. (2012). Plan zagospodarowania przestrzennego wojewodztwa jako instrument zarzadzania rozwojem regionalnym (Spatial development plan for the voivodeship as an instrument for regional development management), CeDeWu, Warszawa, p. 53-60.

8. Poskrobko, B. (2007). Zarzadzanie srodowiskiem (Management of the natural environment), Polskie Wydawnictwo Ekonomiczne, Warszawa, pp. 173

9. Schumpeter, J. (2005). DEVELOPMENT "Journal of Economic Literature", t. XLIII/2005, p. 108 - 120.

10. Williamson, O. (2000). THE NEW INSTITUTIONAL ECONOMICS: Taking Stock, Looking Ahead "Journal of Economic Literature" t. XXXVIII/ 2000, p. 15.

https://bdl.stat.gov.pl/BDL/start Access: 03.01.2019. 